\title{
COMPUTATIONAL MODELING OF SPECIFIC BIOLOGICAL STRUCTURES BEHAVIOR
}

LEMIĆ M ALEKSANDRA, TIHAČEK-ŠOJIĆ LJILJANA, ILIĆ J and ŽIVKOVIĆ R

\author{
School of Dentistry, Belgrade
}

(Received 5. January 2006)

Biomechanical experimental studies are often a subject of interest to many researchers. The results of such investigations give a full insight of complex structural behavior under loading, visualize potential material weaknesses and evaluate if mechanical factors play a substantial role in the pathogenesis of the lesions of the investigated biological structure. The use of FEM enables most of the researchers to abandon the experimental animal models and expand the investigation on computational models, analyzing stress and strain distribution as an indicator of structural biomechanical behavior. The aim of this paper was to present computational modeling of any (human or animal) intact tooth behavior under loading and evaluate the intact tooth stress and strain distribution pattern. For the investigation to be carried out a mathematical model of an intact tooth had to be created. The difference in stress concentration, when masticatory forces are acting lateraly comparing to the ones acting vertically, can be attributed to the basic mechanical principle of leverage which states that forces concentrate at or near the fulcrum. When subjected to lateral loading, tooth with its root acts as a simple lever that fulcrums near the cervical region. This paper offers the new approach in veterinary dental scientific research. Once when a mathematical model is made, it is possible by changing the parameters to investigate different clinical situations. With increasing popularity of veterinary dentistry, the FEM/computational analyses could became a useful tool in biomechanical veterinary dental research due to its noninvasiveness.

Key words: veterinary dentistry, computational analyses

\section{INTRODUCTION}

Experimental studies regarding the biomechanical behavior of biological structures were very often a subject of interest of many researchers. The results of such investigations give the full insight of complex structural behavior under loading, visualize potential material weaknesses and evaluate if mechanical factors played a substantial role in the pathogenesis of lesions of investigated biological structures. 
Such experimental studies are sometimes hard to perform and are limited because some biological structures are hard to reach. The application of experimental devices, such as strain gauges carry the possibility of damaging the tissues, which may influence their mechanical behavior. Introduction of the finite element method (FEM) adapted from the engineering arena proposed great changes into the biomechanic research. The use of finite element analysis is becoming more widespread with rapid advancements in computer technology.

FE modeling of the mechanical performance of musculoskeletal structures has implications in many areas and is useful for biology researchers, surgeons, engineers designing implants or prosthetic appliances (Korioth and Versluis, 1997). Also, a significant insight can be gained by regional modeling (modeling of any isolated structure), where investigation may be directed to mechanics of natural or/and restored structures, including restorative devices.

Although most of veterinary dental papers are dealing with practical problems (Brech, 1997; Visser, 1998; Greene, 2001; Reiter, 2005), there are also papers that are based on scientific subjects of interest (Maretta, 1994; Lindner, 1995; Hamel, 1997; Legendre, 2002; Harvey, 2002). The FEM enables most of the researchers to abandon the animal models and expand the investigation on computational models, analyzing stress and strain distribution as an indicator of structural biomechanical behavior (Cross et al., 1999; Shahar et al., 2003; Hinterhofer et al., 2005).

The aim of this paper was to present computational modeling of any (human or animal) intact tooth behavior under loading and evaluate the intact tooth stress and strain distribution pattern.

\section{MATERIAL AND METHODS}

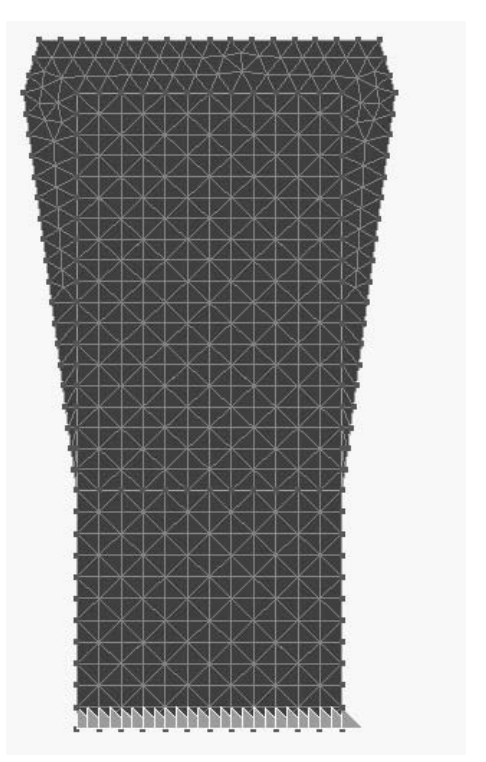

For the investigation to be performed a mathematical model of an intact tooth had to be created. The basic idea was to gain data for tooth stress and strain distribution under loading generally for either human or animal teeth. That is the reason why the model created in this paper does not represent any specific tooth morphology (Figure 1). The model was created in CATIA software. The basic morphology outlines were reconstructed, with the aim to respect crown - root portion relations to each other. The dimensions and basic morphology characteristics were gained from the available literature (Muylle, 1999; Harvey, 2002; Ash and Nelson, 2003; Gioso and Carvalho, 2005).

Figure 1. Final FE model of an intact tooth with defined boundary conditions and generated finite element mesh 
All materials that compose either human or animal teeth were considered isotropic and homogenous and were assigned adequate physical properties values according to literature data (see Table 1). The dental pulp was modeled as a void, because pulp accepts very little of the load (Rubin et al., 1983). Also, the cement was not included in the model, due to its small dimensions and similar biomechanical characteristics to dentin.

Table 1. Physical values for the materials used in this study, Biomaterials properties database, (1996)

\begin{tabular}{|c|c|c|}
\hline & $\begin{array}{c}\text { Elastic modulus } \\
\text { Young's modulus }\end{array}$ & Poisson's ratio \\
\hline \hline Enamel & $84.1 \mathrm{GPa}$ & 0.33 \\
\hline Dentin & $14.7 \mathrm{GPa}$ & 0.31 \\
\hline
\end{tabular}

The boundary conditions were defined as the model was assumed to be fixed $2 \mathrm{~mm}$ apical from the cemento-enamel junction, representing the normal coronal level of the alveolar bone. Therefore the influence of soft tissues on stress and strain distribution was not incorporated in this study.

Loading, simulated in the study, was definied in two ways. The first simulated loading was definied as a $250 \mathrm{~N}$ axial (vertical) force acting on the occlusal surface of the model. The other force was also of a magnitude of $250 \mathrm{~N}$ acting nonaxially representing the lateral forces acting on a tooth.

The finite element mesh for the model was created in NASTRAN program (pre-processing phase), where all later procedures (processing and postprocessing) were performed afterwards.

\section{RESULTS}

The results of the study are presented graphically as maps of stress distribution within the investigated model. Total displacement (translation) and stress distribution were evaluated for two different loading conditions.

Total displacement of the intact tooth after occlusal axial loading is shown in Figure 2. The greatest displacement values are recorded at the occlusal surface, due to tooth structure deformation encountered as a result of loading. Obviously, great deformation happens in the very spot where load is applied and therefore the greatest displacement values are observed. Moving away from the loading point along the long axis of the tooth in the apical direction the displacement decreases. This is probably the mechanism for occlusal load amortization within the intact tooth structure. Such findings are partly recognised as a consequence of the applied boundary conditions. The stress value was also found highest at the occlusal portion of the tooth. Concentration of stresses was greatest at the point of loading. Stress rapidly decreased in the occluso-gingival direction. Close to the cemento-enamel junction (CEJ) the stress again increased and became focused. The pattern of stress distribution through the rest of the tooth structure showed 


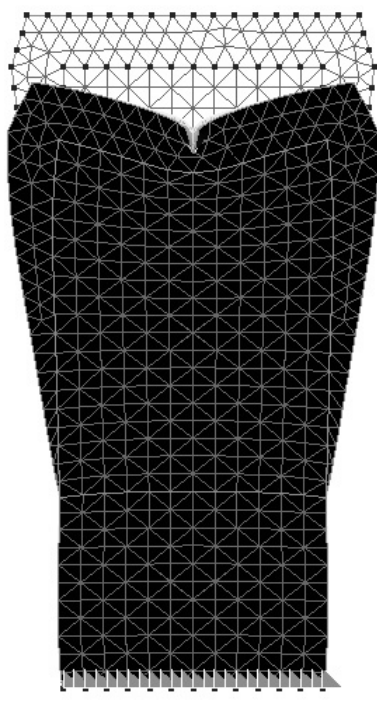

Figure 2. Total displacement of a tooth model after axial (vertical) loading

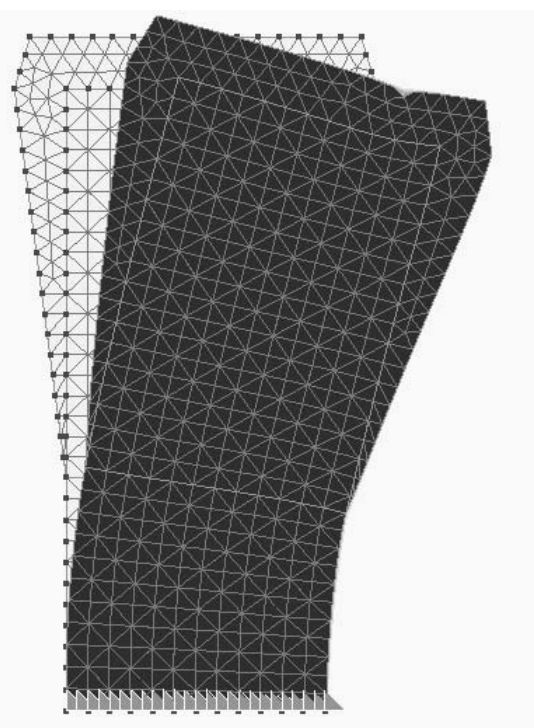

Figure 4. Total displacement of a tooth model after non-axial (lateral) loading

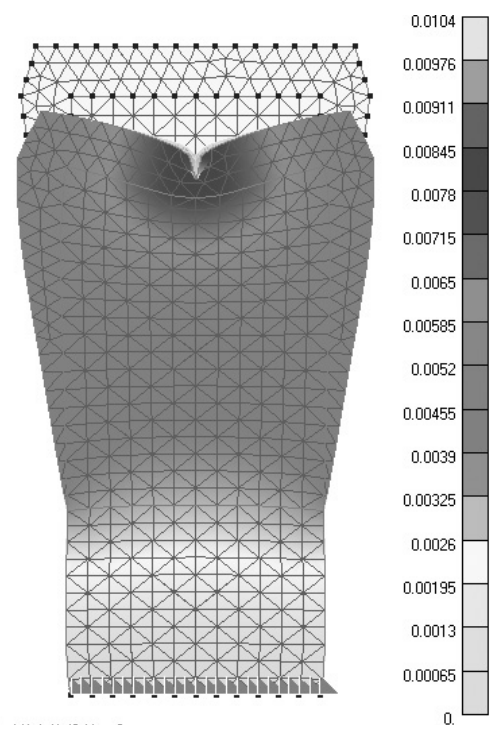

Figure 3. Stress distribution throughout the tooth structure after axial (vertical) loading

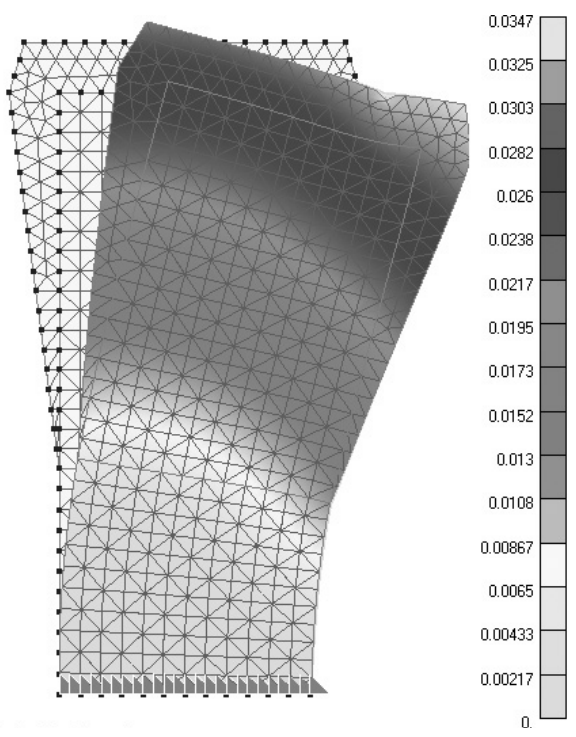

Figure 5. Stress distribution throughout the tooth structure after non-axial (lateral) loading 
reasonably symmetrical distribution with the exception of the occlusal surface and close to the CEJ (Figure 3).

Total displacement of the intact tooth after occlusal non-axial loading is shown in Figure 4. It is interesting to note that most of the large displacement values are recorded at the occlusal surface. Nevertheless, displacement (total translation) is not uniform as it was when axial force was simulated. In this case it is obvious that the entire tooth structure is bending toward the side where the lateral force was acting. As a result of tooth bending a different stress distribution pattern was found. Compressive stress values were highest at the point of force acting on the occlusal surface of the tooth, decreasing in values moving away from the location of loading. However, close to the cemento-enamel junction (CEJ), stress values showed a rapid increase. In this case of non-axial loading at the CEJ, as seen in Figure 5, compressive stress is dominant on the side toward tooth bending, while on the other side tensile stress showed maximal values.

\section{DISCUSSION}

Application of FEM was found to be an appropriate tool for teeth structural behavior investigation following the statement of Yettram et al. (1976) that FEM is applicable to solids of irregular geometry and heterogenous material properties. In fact, a mathematical method permits to evaluate natural systems response under various loads or geometric conditions apart from high dispersion which characterizes experimental data (Ausiello et al. 2001).

Certainly, the assumptions applied in the study could lead to some limitations when interpretating the obtained results. Also it was not possible to include all factors that occur intaorally in this computer simulation, and therefore some simplifications were used. The static loads applied in the study and the corresponding stresses may not reflect the only conditions encountered intraorally.

Based on assumptions involved in the study with the fact that computer simulations were simplified, the results of the study might differ from the values of stresses encountered by teeth in the real situation. Therefore, the results were presented and considered qualitatively, not quantitatively, in order to offer more insight into the general mechanical perfomance of teeth.

Stress distribution within the intact tooth showed that the greatest magnitude of stresses are near the CEJ, in addition to the area immediately beneath the applied load. These findings are consistent with previous reports regarding stress analyses of an intact tooth that axially directed masticatory forces to flow around the stiff enamel and result in the concentration of compression near the CEJ (Yettram et al., 1976; Khera et al., 1988). Characteristic stress distribution throughout an intact tooth under loading is a result of great differences in the mechanical properties of enamel and dentin, two constitutive materials of tooth structure. Enamel is a rigid material and therefore is not deformable, while dentin behaves as a resilient material with great deformation capability. Under occlusal loading a sound tooth distributes the high stresses more homogenously, while the rigid enamel does not deform significantly, but transfers the deformation to the 
lower more resilient dentin, and thus rigidly move over it (Yettram et al., 1976; Ausiello et al., 2001, 2002).

The difference in stress concentration when masticatory forces are acting lateraly can be attributed to the basic mechanical principle of leverage saying that forces concentrate at or near the fulcrum. When subject to lateral loading, a tooth with its root acts as a simple lever that fulcrums near the cervical region. As a result of that phenomenon, as stated by Lee and Eakle (1996), significant lateral forces create tension on one side and compression of equal magnitude on the opposite side. A well known fact is that tooth structure is better designed to withstand compressive forces. Consequently, tooth structure is far more likely to suffer damage when subject to a tensile force of comparable intensity.

These findings are important because lateral forces are encountered in situations like occlusal disharmony, malocclusions or parafunctional movements. The findings are also applicable to veterinary dentistry since lateral forces can occur during abnormal chewing or biting behavior. A contribution to this statement is the study of Brech et al. (1997), which says that canine teeth fractures in military dogs occured most often during attack exercises. Gracis and Orsini (1998), stated similarly that dental traumas in cats and dogs are a consequence of fighting with other animals, and chewing on hard materials such as bones or rocks. Indisputable is that in all mentioned cases lateral forces are dominant and may be the contribution factor to tooth fracture in animals.

Further in vivo and in vitro experiments are needed to validate the results of the calculations described in this paper. The future clinical studies are necessary in other to confirm or reject correlations among experimental and FEM results.

This paper offers a new approach in veterinary dental scientific research. Once when a mathematical model is made, it is possible, by changing the parameters, to investigate different clinical situations. Therefore, establishing a finite element modeling method that is both accurate and practical will be of great benefit in clinical dentistry. With increasing popularity of veterinary dentistry, the FEM/computational analyses could became an useful tool in biomechanical veterinary dental research due to its noninvasiveness.

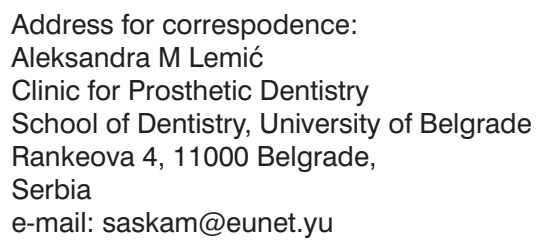

\section{REFERENCES}

1. Ash MM, Nelson SJ, 2003, Wheeler's Dental Anatomy, Physiology and Occlusion, Eighth edition, Elsevier Science, 230-8.

2. Ausiello P, Apicella A, Davidson CL, Rengo S, 2001, 3D finite element analysis of cusp movements in a human upper premolar, restored with adhesive resin-bonded composites, J Biomech, 34, 1269-77. 
3. Ausiello P, Apicella A, Davidson CL, 2002, Effect of adhesive layer properties on stress distribution in composite restorations - a 3D finite element analysis, Dent Mater; 18, 295-303.

4. Biomaterials Properties Database, 1996, University of Michigan QuintessencePublishing, http://www.lib.umich.edu/libhome/Dentistry.lib/Dental tables.html

5. Brech CL, Hamel L, Le Nihouannen JC, Daculsi G, 1997, Epidemiological study of canine teeth fractures in military dogs, $J$ Vet Dent, 14, 2, 51-5.

6. Cross AR, Aron DN, Budsberg SC, Foutz TL, Pearman BT, Evans MD, 1999, Validation of a finite element model of the Kirschner-Ehmer external skeletal fixation system, Am J Vet Res, May, 60, $5,615-20$.

7. Gioso MA, Carvalho VG, 2005, Oral anatomy of the dog and cat in veterinary dentistry practice, Vet Clin North Am Small Anim Pract, Jul, 35, 4, 763-80.

8. Gracis M, Orsini P, 1998, Treatment of traumatic dental displacement in dogs: six cases of lateral luxation, J Vet Dent, 15,2, 65-72.

9. Greene SK, 2001, Equine dental advances, Vet Clin North Am Equine Pract, Aug,17,2, 319-34.

10. Hamel L, Brech CL, Besnier NJ, Daculsi G, 1997, Measurement of biting-pulling strength developed on canine teeth of military dogs, $J$ Vet Dent, 14, 2, 57-60.

11. Harvey CE, 2002, Shape and size of teeth of dogs and cats-relevance to studies of plaque and calculus accumulation, $J$ Vet Dent, Dec,19, 4,186-95

12. Hinterhofer C, Ferguson JC, Apprich W, Haider H, Stanek C, 2005, A finite element model of the bovine claw under static load for evaluation of different flooring conditions, $N Z$ Vet $J$, Jun, 53 , 3,165-70

13. Lee WC, Eakle WS, 1996, Stress-induced cervical lesions: Reiew of advances in the past 10 years, $J$ Prosthet Dent, 75, 487-94.

14. Lindner DL, Maretta SM, Pijanowski GJ, Johnson AL, Smith CW, 1995, Measurement of bite force in dogs: a pilot study, $J$ Vet Dent, Jun, 12, 2, 49-52.

15. Khera SC, Goel VK, Chen RCS, Gurusami SA, 1988, A three-dimensional finite element model, Oper Dent, 13, 128-37.

16. Korioth TWP, Versluis A, 1997, Modeling the mechanical behavior of the jaws and their related structures by finite element (FE) analysis, Crit Rev Oral Biol Med, 8, 1, 90-104.

17. Legendre $L F, 2002$, Malocclusions in guinea pigs, chinchillas and rabbits, Vet Clin North Am Small Anim Pract, May, 43, 5, 385-90.

18. Maretta SS, Eurell JA, Klippert L, 1994, Development of a teaching model for surgical endodontic access sites in the dog, $J$ Vet Dent, Oct, 11, 3, 89-93.

19. Muylle S, Simoens $P$, Verbeeck R, Ysebaert MT, Lauwers $H$, 1999, Dental wear in horses in relation to the microhardness of enamel and dentine, Vet Rec, May, 15,144, 20, 558-61.

20. Rubin C, Krishnamurthy N, Capilouto E, Yi H, 1983, Stress Analysis of the human tooth using a three-dimensional finite element model, J Dent Res, 62, 2, 82-6.

21. Reiter AM, Lewis JR, Rawlinson JE, Gracis M, 2005, Hemisection and partial retention of carnassial teeth in client-owned dogs, $J$ Vet Dent, Dec, 221, 4, 216-26.

22. Shahar R, Banks-Sills L, Eliasy R, 2003, Stress and strain distribution in the intact canine femur: finite element analysis, Med Eng Phys, Jun, 25, 5, 387-95.

23. Visser CJ, 1998, Restorative dentistry, Crown therapy,Vet Clin North Am Small Anim Pract, Sep, 28, 5,1273-84.

24. Yettram AL, Wright KWJ, Pickard HM, 1976. Finite element stress analysis of the crowns of normal and restored teeth, J Dent Res, 55, 6, 1004-11. 


\title{
KOMPJUTERSKO MODELIRANJE SPECIFIČNIH BIOLOŠKO-STRUKTURNIH ODLIKA ZUBA
}

\author{
LEMIĆ M ALEKSANDRA, TIHAČEK-ŠOJIĆ LJILJANA, ILIĆ J i ŽIVKOVIĆ R
}

\section{SADRŽAJ}

Biomehanička eksperimentalna istraživanja pružaju potpuni uvid u kompleksno ponašanje bioloških struktura pod opterećenjem, vizualizuju potencijalna slaba mesta u samom materijalu i analiziraju da li mehaničko opterećenje igra ulogu u nastajanju pojedinih patoloških lezija. Primena MKE omogućuje istraživačima da napuste istraživanja na eksperimentalnim životinjama, i da se fokusiraju na kompjuterske modele i analizu distribucije napona i deformacija koji su pokazatelji biomehaničkog ponašanja strukture. Cilj ovog rada je bio da se prikaže ponašanje kompjuterskog modela intaktnog zuba nakon opterećenja i evaluira distribucija napona i deformacija. Da bi se sprovelo ovo istraživanje bilo je potrebno kreirati digitalni model bilo kog zuba (ljudskog ili životinjskog). Razlike u distribuciji napona kod lateralnog opterećenja u odnosu na vertikalno mogu se pripisati jednostavnom mehaničkom principu poluge, koji kaže da se sile koncentrišu na mestu oslanjanja. Kada je zub izložen lateralnim silama, on se ponaša kao jednostavna poluga čiji je oslonac u cervikalnom delu.

Ovaj rad unosi novi pristup u istraživanjima u veterinarskoj stomatologiji. Jednom izrađen model, omogućava da se menjanjem parametara ispituju i analiziraju različite kliničke situacije. Sa narastajućom popularnošću veterinarske stomatologije analize MKE mogu postati veoma koristan alat u biomehaničkim istraživanjima, posebno zbog svoje neinvazivnosti. 